\title{
Organizational Justice in Performance Appraisal System and Work Performance: Evidence from an Emerging Market
}

\author{
Ari Warokka ${ }^{1}$, Cristina G. Gallato ${ }^{1}$ and Thamendren a/I Moorthy ${ }^{2}$ \\ ${ }^{1}$ Othman Yeop Abdullah - Graduate School of Business (OYA GSB), Universiti Utara Malaysia \\ (Northern University of Malaysia), Malaysia \\ ${ }^{2}$ Malaysia
}

\begin{abstract}
This study aimed at extending the literature of the effect of performance appraisal on productivity and employees by connecting the employees' perception on fair performance appraisal and organizational justice-considered practices to job satisfaction and work performance. Prior studies did not explore much this relation due to the geographical sample limitation and governance practice context. Participants of this research were employees of large and well-established companies, which were considered to have well and transparent appraisal systems and a perfect recently context to find the effect of organizational justice conflict. Questionnaires were used and processed with factor analysis and regression to examine the simultaneous effects of few independent variables on a dependent variable. The results reveal that the interactional justice has more influence than other types of organizational justice in evaluating employee's performance, which is contrary with previous researches. Employees are more concerned on interaction during and after the evaluation process. They are keen on knowing how they have been evaluated and what the feedback of their superior is after the performance appraisal process. It provides strong support for the relationship between employee perception of organizational justice in performance appraisal system and work performance. It also supports a significant relationship between performance appraisal satisfaction and work performance. The important implication for organization is a pivotal role of the employees' perceptions of the success or failure of a system. Therefore, the management has to keep in view the perceptions of their employees, while designing or modifying the appraisal system.
\end{abstract}

Keywords: Organizational Justice, Performance Appraisal System, Job Satisfaction, Work Performance.

\section{Introduction}

Performance appraisal is an integral part of the Human Resource Management system (Longenecker \& Goff, 1992). An organization implements the performance appraisal system to allocate rewards for the employee, provide development advice as well as to obtain their perspectives, and justice perception about their jobs, department, managers, and organization. Performance appraisal is an ongoing communication process between employees and supervisors. Supervisors should set expectations, monitor performance, and provide feedback to employees. By having this information, they will direct and develop employee performance by identifying training and development needs, correcting, and

Copyright (C) 2012 Ari Warokka, Cristina G. Gallato and Thamendren a/l Moorthy. This is an open access article distributed under the Creative Commons Attribution License unported 3.0, which permits unrestricted use, distribution, and reproduction in any medium, provided that original work is properly cited. Contact author: Ari Warokka E-mail: ari.warokka@uum.edu.my 
determining raises and promotions (Seldon, Ingraham, \& Jacobson, 2001).

In the other side, performance appraisal also provides employees with useful feedback which they can apply it to improve their performance (Ahmed, 1999). The feedback includes suggestions to change and encouragement. Performance appraisal system has a significant impact on the employee perception of justice which it will affect the attitudes and behavior of the employee; alternately, it will influence the performance of the organization (Ahmed, Ramzan, Mohammad \& Islam, 2011).

The employee's perception of fairness is the ultimate check for the success of the system. According to the organizational justice theory, the efficacy of the appraisal system also depends upon the perception of fairness related to it. The components of fairness, procedural as well as distributive, should have a positive impact on the employee in order to make him accept the whole procedure and its results without any reluctance. This fact is also evident in the studies' findings, which reveals the employees consider the procedure-based fairness is more important than the equaldistribution justice is (Alexander \& Ruderman, 1987). In addition, addition, they are willing to accept some injustice in the outcomes if they perceive the procedure itself to be fair. Therefore, the acceptance of the evaluation system also depends on the perceived fairness associated to it. With that, it is also important that they perceive that they are being evaluated against what they are actually supposed to do on the job. That is the evaluation instrument clearly measures their performance against their job-related activities (Sabeen \& Mehboob, 2008).

According to Robbins and Judge (2007), perception is a process by which individuals organize and interpret their sensory impressions in order to give meaning to their environment. In reality, the objectives often vary and differ from one's perception due to every person has different behavior and thought. Therefore, it is common that there is more disagreement among people's view. Factors that influence someone's perceptions are from their nature characteristics, which include his or her attitudes, personality, motives, interest, past experiences and expectations.

Prior studies reveal that employee perception of fairness of performance appraisal is a significant factor in employee acceptance and satisfaction of performance appraisal (Ahmed et al., 2011). A good perception will create a positive working environment in the organization, while a negative perception will create many problems to the organization that finally, it will affect the company performance. These perceptions depend on the manager or supervisor's actions and behaviors toward the employee. If the immediate superior employ fair and transparent performance appraisal benefiting to the employee, then hypothetically, the latter has a good perception on him.

Relating to the current business practices, many organizations are using the performance appraisal system for formality purposes only, whereas potentially it can be used for providing feedback to the employee. Those practices are in line with the research of Shen (2004) that reports a lack of transparency and feedback in the performance appraisal process. Because of this scenario, it has created many problems especially with the employee's perception towards the performance appraisal system in the organization.

Meanwhile, Bretz, Milkovich and Read (1992) document that the most important performance appraisal issue faced by organizations is the perceived fairness of the performance review and the performance appraisal system. They reported that most employees perceived their performance appraisal system as neither accurate nor fair. Even Skarlicki and Folger (1997) find that the appraisal process can become a source of extreme dissatisfaction when employees believe the system is biased, political, or irrelevant. 
Therefore, intuitively, people will only be satisfied with a performance appraisal process if it fulfills the criteria of "fairness," which expressed by many researchers as organizational justice. In other words, the employees need a good and fair performance appraisal system to provide them with feedbacks regarding their job, leading to their job satisfaction, and generating an increased work performance (Suliman, 2007).

Based on those prior studies, there is a relationship between organization justice, job satisfaction, and work performance. This association becomes important due to the complex and intensified competition has made the human resources as the key of any organization's survival. Human resource is the underlying factor for innovation and sensitivity barometer to the business change. From this point of view, it is important to get valid and up-to-date information of the relationship between those three variables (organization justice, job satisfaction, and work performance). We explored the supposed empirical findings on the relationship between employee's perception on justice and work performance. At the same time, we hypothesized job satisfaction partially was mediating that relationship.

Our study will provide some important contributions, such as a testing the magnitude of three well-recognized types of the fair-performance appraisal system with employee's perception and an expanding the simultaneously effect of three-type fairness of the performance appraisal system on work performance. In this study, we will experiment on the mediating effect of performance appraisal satisfaction with the relationship between each type of fair-performance appraisal system and work performance. The expected empirical findings of this study will be valuable information to set and update the current performance appraisal leading to increased employees' perception of the work system and its measurement. The satisfied employees, as reported in many studies, perform better and higher performances than the unsatisfied ones are.
To present the empirical findings, the paper is organized as follows. The literature review and prior studies on organizational justice, satisfaction on performance appraisal system, and work performance variables are briefly outlined in Section 2. The methodology and research model is described in Section 3, followed by the research results and discussion in Section 4. We provide some concluding remarks in Section 5.

\section{Literature Review and Theoretical Framework}

The fact that businesses rely on performance management systems to evaluate how well employees perform becomes a center of stage of many humanresource managers' focus in winning the heart of talented employees, retaining to keep working for the company, and maintaining them to perform productively and innovative. The employee appraisal processes can provide useful information to employers, as well as positively and negatively affect employee performance. As prior studies partially and individually have explored the relationship between employee's perception of the fairness of performance appraisal system and work performance, in this study, we proposed employee's satisfaction on performance appraisal would moderate the effect of the fairness-perceived on the performance appraisal system on work performance. The theoretical framework is built from these variables and its' supporting empirical findings.

\section{Performance Appraisal System}

In the organizational setting, performance appraisal is defined as a structured formal interaction between a subordinate and supervisor, that usually takes the form of a periodic interview (annual or semiannual), in which the work performance of the subordinate is examined and discussed (Moorhead \& Griffin, 1992; Sabeen \& Mohboob, 2008). In the performance appraisal, the focus is to identify weaknesses and strengths as well as opportunities for improvement and skills development (Aguinis, 2007). A 
performance appraisal involves measuring job performance in which mainly captures an essential element of the performance appraisal process without specifying the actual techniques used for measurement (Kavanagh, Benson \& Brown, 2007). According to Shen (2004), the performance appraisal is the process of identifying, observing, measuring, and developing human resources in organizations. In order the appraisal system to be effective, the system needs to be accepted and supported by its employees. At the same time, performance appraisal is a process of judgment and evaluating of the subordinate's performance by the supervisor as well.

From those prior studies, arguably we can define that there are four activities in the performance appraisal cycle in organizations, namely, defining the performance, measuring and evaluating the performance, giving feedback to the employee, and applying the results in the different organizational system. By using this performance appraisal method, an organization can evaluate the level of performance of an employee and keep the record of their performance achievement as well.

Meanwhile, one important function of performance appraisals is to encourage, guide, and improve employee performance. To be effective, the performance appraisal must be relevant and the measurement standards must be clear. Relevance refers to the degree to which the performance measurement includes necessary information; that is, information that indicates the level or merit of a person's job performance. To be relevant, the appraisal must include all the pertinent criteria for evaluating performance and exclude criteria that are irrelevant to job performance.

Archer North (1998) argued that an effective performance appraisal can lead to higher job satisfaction and reduced absenteeism and turnover rates. Mohrman, Resnick-West, \& Lawler (1989) documented some potential benefits of highly performance appraisal policy, such as increased motivation to perform effectively, gained new insight into staff and supervisors, distributed rewards on a fair and credible basis, and encourage increased self-understanding among staff as well as insight into the kind of development activities that are of value. Richards (2010) found that performance appraisal can provide an indication of areas of training need as well as direction for leadership development, performance improvement, and succession planning.

If performance appraisals are perceived as unfair, therefore, the benefits of performance appraisals can diminish rather than enhance employee's positive attitudes and performance (Thomas \& Bretz, 1994). Specifically, the perceptions of procedural unfairness can adversely affect employee's organizational commitment, job satisfaction, trust in management, performance as well as their work-related stress, organization citizenship behavior, theft, and inclination to litigate against their employer. If an appraisal within a company is carried out without any rules, transparency, and prospect of things linked to it, it might cause severe troubles, not only can it damage the climate at workplace and lead to decrease in productivity. It also can end up with ethical and legal problems. Manager should always be aware of what he or she is doing and what consequences might it have when appraising performance.

In general, research indicates (Smither, 1998) that perceptions of fairness arise from consideration of the outcomes received (outcome fairness); the procedures used to determine those outcomes (procedural fairness); and the way in which the decision-making procedures were implemented and explained (interpersonal fairness). This description of the components of fairness draws heavily on the research and literature in the area of organizational justice. Therefore, to handle the issue of managing organization effectively, it is important to any top management to set a performance appraisal system accurately and meet the employees' sense of fairness. 
The conclusion derived from the prior studies may provide insights to the managers as they attempt to develop and implement appraisal processes that are viewed as being valid, and as they attempt to enhance the benefits that may be obtained from engaging in this process. From the literature review, it shows how significant a performance appraisal process is in an organization. While the performance appraisal is important, the fairness and reliability are influential too during the performance appraisal process. Without these, it will create a perception of dissatisfaction with the performance appraisal system. Hence, as the evaluator, the immediate supervisor must be always in a neutral mood, so that there is no bias or unfairly rated performance appraisal.

\section{Organizational Justice}

The increasing-concern of most employees in many organizations nowadays is the fairness at work, which is known also as the organizational justice (Byrne \& Cropanzano, 2001). This issue, especially, related to the performance appraisal fairness and what is behind the different performance point of each employee receives. The issue of fairness is critical to performance administration and most every phase of labor management. Employees will act to restore equity if they perceive an imbalance. In evaluating the fairness of their performance appraisal, employees will balance inputs (e.g., work effort, skills) against outcomes (e.g., pay, privileges).

Organizational justice researchers divide the concept of fairness into three primary types. The first commonly accepted type of justice is referred to as "distributive" justice. In the distributive-oriented perspective, the fairness of the outcomes of a particular decision is the main consideration. "Procedural" justice, the second type, concerns about the fairness of the processed that lead to the outcome. The majority of research conducted in the organizational justice's field has put these two areas as the foundation in the last twenty years (Byrne \& Cropanzano, 2001). Those studies indicate that people will accept a certain amount of unfairness in distribution if they perceive that the process by which the distribution decisions were made is fair. A third type of justice is often referred to as "interactional" justice. Many scholars defined interactive-oriented justice as the fairness of the interpersonal treatment that one receives at the hands of an authority figure during enactment of organizational processes and distribution of outcomes (Bies \& Moag, 1986). The interactional justice concept has been included as an interpersonal aspect of procedural justice. It also plays as a distinct construct along with procedure-oriented and distributive justice (Skarlicki \& Folger, 1997). In 2007, Robbins and Judge resumed their findings and reinforced distributive, procedural, and interactional justice as the three different components of organizational justice.

\section{Organizational Justice and Performance Appraisal}

The basic question of the Greenberg's study (1986a) on what makes a performance appraisal appear to be fair was one of the first to apply organizational justice theory to performance evaluation. Greenberg (1986) investigated if it was what one receives (rating or other outcome) or how it is decided that makes an appraisal seem fair. His work (Greenberg, 1986) supported earlier research by Landy, Barnes, and Murphy (1978) which showed that employees were more likely to accept an appraisal system and believe that their performance was rated fairly under certain conditions. According to Landy and Farr (1980), a fair evaluation is one that contains definite procedural elements regardless of the outcomes of the evaluations themselves. The work of Folger, Konovsky and Cropanzano (1992) supported the prior findings by documenting three essential factors, i.e. adequate notice, equitable hearing, and judgment based on evidence were used to extend the application of justice to performance appraisal.

In the context of Malaysia, employees were more satisfied when they felt they were rewarded fairly for the work they have 
done by making sure rewards were for genuine contributions to the organization and consistent with the reward policies (Fatt, Khin \& Heng, 2010). Further, the study reported that the justice climate of the procedural, distributive and interactional as the main employees' perception on fair treatment (Fatt, Khin \& Heng, 2010). It suggested the provision of training of managers as one way to ensure they could treat the employees fairly. By using the UEA and Saudi Arabia context, Suliman (2007) reported that organization justice was overall perceptions of fairness in all organizational processes and practices. Those perceptions are assumed to influence the behavior and work outcome.

Prior studies also revealed that the employees' perception on each component of organizational justice influenced their work performance, especially when they were under the performance appraisal process. For example, Fernandes and Awamleh (2006) reported that the employees' perception on distributive justice was expressed by the employees' concern to the distribution of resources and outcome. This concern also affected the employees' satisfaction with their work outcome, which will lead inevitably to the organization effectiveness (Suliman, 2007). Performance appraisal system, in which the employees perceived it as an unfair process, will potentially become a source of disputes, mistrust, disrespect, and other social problems.

Tyler and Belliveau (1995) argued that fair procedures or procedural justice tended to inspire feelings of loyalty to one's team or group, legitimize the authority of leaders, and help to ensure voluntary compliance with the rules. Even in the context of organizational decision-making, procedural justice has a positive impact on variety of employee's decision and some emotional and behavioral reactions. These consequences of procedural justice include variables such as organizational commitment, trust, satisfaction, compliance with decision and performance. If procedural unfairness is perceived, then it has the capacity to dismantle the process and undermine the outcome (Heslin, 1998).

The work of Cropanzano and Mitchell (2005) argued that the interactional justice in the workplace is grounded in social exchange theory and norm of reciprocity. From the social exchange perspective, employees expect fair, honest, and transparent treatment from the organization and/its agents. Meanwhile, according to the norm of reciprocity, employees are more likely to behave positively through greater commitments to the organization's values and goals, demonstrate an increased job satisfaction and organizational citizenship behavior, improve job performance, and reduce unproductive behavior (Cohen-Charas \& Spector, 2001; Colquitt, Conlon, Wesson, Porter, \& Yee, 2001). Specifically, Bies and Moag (1986) argued that authorities should treat others with respect, adhere to specific rules of fair interpersonal communication, and refrain from making improper statements.

Ismail, Mashkuri, Sulaiman, and Wong (2011) found that the Malaysian employees' fair-perceived performance appraisal affected job satisfaction, which its influence becomes significant after being mediated by interactional justice. Their empirical findings have firmly opened other fields to be extended, especially to test what type in nature actually each variable, whether it is more powerful as independent variable or mediating variable.

\section{Performance Appraisal and Work Performance}

According to Aguinis (2007), performance is about employee's specific behavior. It means something what employees do and not about what employees produce or the outcomes of their work. Performance is determined by a combination of declarative knowledge, procedural knowledge, and motivation. This definition has two important facets, i.e. task and contextual. Task performance or work performance refers to the specific activities required by one's job. Meanwhile the contextual one 
refers to the activities required to be a good member of the organization or as a citizen. Both facets are the determinants for organizational success; therefore, both should be included in a performance management system.

Prior studies (Kuvaas, 2006) reported that the employees' satisfaction on performance appraisal determined their work performance. It means a properly managed performance appraisal will lead to high employees' satisfaction, and it sequentially elevates high work performance. In the work of Kuvaas (2006), which studied the different relationships between perceptions of developmental performance appraisal and work performance, the result showed that the relationship between perceptions of developmental performance appraisal and self-reported work performance was mediated by employees' intrinsic motivation and strongly moderated by their autonomy orientation. It is in line with the findings of Folger, Konovsky, and Cropanzano (1992), indicated that employees react differentially to performance appraisal based on their perceptions of the fairness of the appraisal, in terms of distinctive substantive aspects of organizational justice. In addition, the findings have encouraged considering other independent variables as a moderator of relationship between the appraisal reaction (feeling satisfied with the performance appraisal system) and contextual antecedents (performance appraisal process).

The influence of performance appraisal and work performance becomes taking more attention due to the number of studies, which examined the effects of performance appraisal systems on employee, provides solid empirical findings that employees' opinions regarding the performance appraisal (PA) process are highly critical to the long-term effectiveness and the success of the system as well (e.g. Kuvaas, 2006; Pettijohn, Pettijohn \& Taylor, 2000; Pettijohn, Pettijohn, Taylor \& Keillor, 2001). These studies have used several surveys and questionnaires to assess individuals' reactions to various aspects of the PA system. Furthermore, the results revealed that basically employees would experience the greatest levels of satisfaction when fully they understand the criteria used for PA evaluation, agree with the criteria used, feel the results of the evaluation have an impact on their level of compensation, and believe that the appraisal process is fair.

In the work of Kuvaas (2006), which surveyed 593 employees from 64 Norwegian banks regarding their opinions and perceptions of the appraisal process on work performance, organizational commitment, and turnover intention, the findings revealed that there was a direct relationship between PA satisfaction and employee outcomes. The results also indicated that the relationship between performance appraisal satisfaction and work performance was both mediated and moderated by employee's intrinsic work motivation.

The contending research's results from the Western countries' context may not be generalized to the emerging countries' one, which have different environment. In addition, there are possibilities that the findings of developed-countries' researchers may bear significance in the Southeast Asian environment, as founded by Vance, McClaine, Boje, and Stage (1992). They concluded a difference in management style between US and the Pacific Rim countries. In light of the insufficient findings in this area, there are two purposes of the present research: (1) to explore the relationship between performance appraisal satisfaction and work performance, by covering all three components of organizational justice, which in the prior cited-studies covered only one or two component out of the three those justice components. Second, it is to examine performance appraisal satisfaction as mediating variable to test the relationship. 


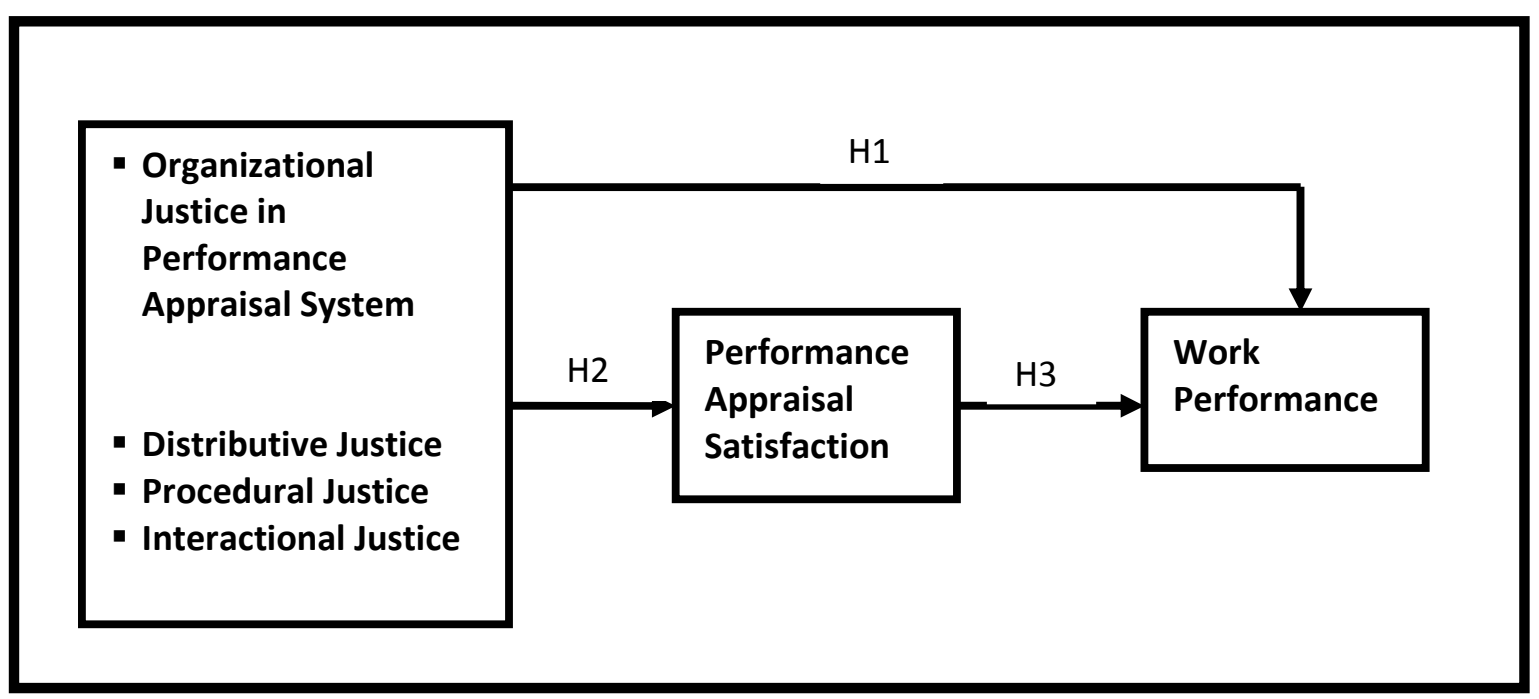

Fig 1.Conceptual Framework

Figure 1 above shows the variables that are involved in this study. There is a measured variable and some independent variables. The dependent variable is work performance, and the predictor variable is organization justice, which is further split into distributive justice, procedural justice and interactional justice. The organization justice is hypothesized to influence the organizational performance appraisal satisfaction and eventually will affect the organization outcomes or employee's work performance.

\section{Methodology}

\section{Research Design}

This study involves the correlational study. According to Cavana, Delahaye and Sekaran (2001), when the researcher is interested in delineating the important variables that are associated with the problem it is called the correlational study. The study employs a set of questionnaires to gather the data, find a combination of variable by using Factor Analysis, and then the obtained-data will be analyzed in a regression model.

\section{Sample, Instrumentation, and Measures}

This study used a non-probability sampling, which is convenience sampling, where the elements in the population have no probabilities attached to their being chosen as sample subjects (Cavana, Delahaye, \& Sekaran, 2001). This means that the findings from the study of the sample cannot be confidently generalized to the populations who are conveniently available to provide it. By using this method, it is easier to collect data because the researcher can choose the respondent freely among the employee of construction companies in Kuala Lumpur. Data was gathered from the companies' staffs personally and treated each employee's response as an individual data source. For this study about 150 questionnaire-sets of were distributed among the employees of construction companies and successfully collected $66 \%$ of them (100 sets) through the Human Resource Department. The number of this sample exceeds the minimum sample of 30 participants as required by probability sampling technique, showing that it may be analyzed using inferential statistics (Sekaran, 2003).

Essentially, there are three main variables, which are organizational justice, performance appraisal satisfaction and work performance. The independent variables for this study consist of three components of organizational justice, which are distributive justice, procedural justice and interactional justice. Meanwhile, the mediating variable is 
performance appraisal satisfaction, and the dependent variable is the work performance.

In this study, work performance is used to measure whether the organizational justice and performance appraisal satisfaction affect work performance or not. The items are adapted from Fernandes and Awamleh (2006), which are five statements used to measures work performance. The second part of the questionnaire measures organizational justice, which consists of distributive, procedural and interactional justice. The items are adapted from Moorman (1991); there are five items in distributive justice, seven items in procedural justice and six items in interactional justice. The third of the questionnaire measures the performance appraisal satisfaction. This section is adapted from Cook and Crossman (2004), there are seven items measures for this variable.

\section{Data Analysis}

To analyze the obtained data, we firstly employ an exploratory factor analysis to assess the validity and reliability of measurement scales (Hair et al., 1998). Secondly, to confirm the validity and reliability and the collinear problem of constructs, we use Pearson's correlation analysis and descriptive statistics (Tabachnick, Barbara, \& Fidell, 2001; Yaacob, 2008). Finally, multiple regression analysis was recommended to assess the magnitude and direction of each independent variable, and measure the effect of the mediating variable in the relationship between many predictor variables and one measured variable (Foster, Stine \& Waterman, 1998). Baron and Kenny (1986) suggest that to test mediating effect in the hypothesized model, the researcher should estimate the three following regression equations: firstly, doing the regression of the mediating variable on the dependent variable. Secondly, we employ the regression of the measured variable on the predictor variable. Thirdly, we do the regression of the dependent variable on both the independent variable and on the mediating variable.

Based on this procedure, a mediating variable can be easily considered when it meets three conditions: first, the predictor variable should be significantly correlated with the intermediary variable. Second, the independent variable and the mediating variable should also be considerably correlated with the measured variable. Third, the mediating variable should be significantly correlated with the dependent variable. If this condition is properly implemented, a previously significant effect of independent variable should be reduced to non-significance or reduced in terms of effect size after the inclusion of mediator variable into the analysis (Wong, Hui, \& Law, 1995). In this regression analysis, standardized coefficients (standardized beta) were used for all analyses (Jaccard, Turrisi, \& Wan, 1990).

\section{Finding \& Discussion}

\section{Factor Analysis}

A principal component analysis with varimax rotation was conducted on all eighteen items in order to measure the organization justice. Table 1 shows the rotated component of organizational justice that was used for this study. 
Table 1: Factor Analysis-Rotated Component of Organizational Justice

\begin{tabular}{|c|l|c|c|c|}
\hline Item & \multicolumn{1}{|c|}{ Construct } & \multicolumn{3}{|c|}{ Component } \\
\cline { 2 - 4 } & & $\mathbf{1}$ & $\mathbf{2}$ & $\mathbf{3}$ \\
\hline 1 & Supervisor treated me with kindness and consideration & $\mathbf{. 8 6 7}$ & .174 & .208 \\
\hline 2 & Supervisor showed concern for my rights as an employee & $\mathbf{. 8 3 1}$ & .213 & .236 \\
\hline 3 & Supervisor took steps to deal with me in a truthful manner & $\mathbf{. 8 2 5}$ & .292 & .193 \\
\hline 4 & Supervisor was able to suppress personal biases & $\mathbf{. 7 7 8}$ & .207 & .118 \\
\hline 5 & $\begin{array}{l}\text { Supervisor provided me with timely feedback about the ratings } \\
\text { and its implications }\end{array}$ & $\mathbf{. 7 3 9}$ & .335 & .192 \\
\hline 6 & Supervisor consider my viewpoint & $\mathbf{. 7 0 9}$ & .261 & 334 \\
\hline 7 & $\begin{array}{l}\text { PAS is designed to collect accurate information for making } \\
\text { appraisal ratings }\end{array}$ & .217 &. $\mathbf{7 9 4}$ & .324 \\
\hline 8 & $\begin{array}{l}\text { PAS is designed to provide opportunities to appeal or challenge } \\
\text { the appraisal rating }\end{array}$ & .271 &. $\mathbf{7 8 9}$ & .295 \\
\hline 9 & PAS is designed to have all sides affected by rating & .186 &. $\mathbf{7 5 3}$ & .425 \\
\hline 10 & $\begin{array}{l}\text { PAS is designed to generate standards so that appraisal rating } \\
\text { made consistency }\end{array}$ & .194 &. $\mathbf{7 4 7}$ & .459 \\
\hline 11 & $\begin{array}{l}\text { PAS is designed to hear the concerns of all those affected by } \\
\text { appraisal rating }\end{array}$ & .374 &. $\mathbf{7 0 4}$ & .243 \\
\hline 12 & $\begin{array}{l}\text { PAS is designed to provide useful feedback regarding the } \\
\text { appraisal rating }\end{array}$ & .438 & $\mathbf{. 6 7 3}$ & .293 \\
\hline 13 & $\begin{array}{l}\text { PAS is designed to allow for requests for clarification or } \\
\text { information about appraisal }\end{array}$ & .444 & $\mathbf{. 6 7 3}$ & .241 \\
\hline 14 & Performance was fairly rated for the amount of effort & .198 & .281 & $\mathbf{. 8 3 3}$ \\
\hline 15 & Performance was fairly rated for the work I have done well & .277 & .301 &. $\mathbf{7 6 6}$ \\
\hline 16 & Performance was fairly rated by considering my responsibilities & .250 & .394 & $\mathbf{7 5 9}$ \\
\hline 17 & $\begin{array}{l}\text { Performance was fairly rated in view of the amount of } \\
\text { experience }\end{array}$ & .148 & .330 & $\mathbf{. 6 9 4}$ \\
\hline 18 & Performance was fairly rated for the stresses and strains & .253 & .234 & $\mathbf{. 6 9 3}$ \\
\hline
\end{tabular}

The findings of this analysis indicated that Kaiser-Meyer-Olkin (KMO) measure of sampling adequate has a value of 0.9 , and the Bartlett sphericity test is significant (Chi-square is 1628.13, p <0.001). The results reveal that three components are extracted with eigen value above 1.

The first component was labeled as 'interactional justice'. It is operationalized as a part of interpersonal communication that is important during and after the performance appraisal process. In this component, there were six items starting from item 1 to 6 (refer to Table 1) were used to measure this construct. The variance explained in these items was 26.45 percent. The second component is 'procedural justice'. It measured by using seven items whereby from the item 7 to item 13 (see Table 1). This construct is operationalized as the fairness of the organization procedures that are used to take decisions. The results from the decision will be related to employee's attitudes, especially performance appraisal results. The variance explained by this scale is 25.84 percent. Component number three was labeled as 'distributive justice' and was measured by five items whereby from the item 14 to item 18 (see Table 1). This scale measures the employees' perception on fairness outcome that organization should provide to them. The variance explained by this scale was 21.68 percent.

\section{Performance Appraisal Satisfaction and Work Performance}

Table 2 shows the results of factor analysis between performance appraisal satisfaction and work performance. A principal component analysis was performed using varimax with KaiserMeyer-Olkin (KMO). 
Table 2: Factor Analysis-Rotated Component of Performance Appraisal Satisfaction and Work Performance

\begin{tabular}{|c|l|c|c|}
\hline Item & & \multicolumn{1}{|c|}{ Construct } & Component \\
\cline { 2 - 4 } & & $\mathbf{1}$ & $\mathbf{2}$ \\
\hline 1 & I am satisfied with the performance appraisal process & $\mathbf{8 8 1}$ & .030 \\
\hline 2 & Current PA is fair and unbiased & $\mathbf{. 8 7 5}$ & .158 \\
\hline 3 & My leader takes my performance appraisal review discussion seriously & $\mathbf{. 8 6 6}$ & .163 \\
\hline 4 & Performance appraisal process was a satisfying experience & $\mathbf{. 8 5 4}$ & .035 \\
\hline 5 & Performance appraisal process help me to find out about my level of performance & $\mathbf{. 8 4 6}$ & .162 \\
\hline 6 & If don't agree with PA score, there is appeal process &. $\mathbf{8 0 8}$ & .223 \\
\hline 7 & PA review discussion is the only time I get feedback about my performance &. $\mathbf{6 8 7}$ & .126 \\
\hline 8 & Overall, I am a very good performance & .070 &. $\mathbf{8 5 0}$ \\
\hline 9 & I always reach my performance target & .154 &. $\mathbf{8 3 6}$ \\
\hline 10 & I consider my performance better than the average employee in this firm & .207 & $\mathbf{. 8 3 6}$ \\
\hline 11 & I feel that my performance is reflective of my abilities & .252 &. $\mathbf{8 0 3}$ \\
\hline 12 & I feel that my job conditions are not allowing me to perform at high level & .007 &.-378 \\
\hline
\end{tabular}

The findings of this analysis indicated that Kaiser-Meyer-Olkin (KMO) measure of sampling adequate has a value of 0.8 , and the Bartlett sphericity test is significant (Chi-square is 813.06, $\mathrm{p}<0.001$ ). The test reveals that three components are extracted with eigen value about 1 . One item was taken out from the findings due to loading factor. The value of items is below than 0.50 . Hence, this item was dropped from the analysis.

The first component was labeled as 'performance appraisal satisfaction'. It is operationalized as a part of level of the employee satisfied with the performance appraisal system. There were seven items whereby from the item 1 to item 7 (see Table 2) used to measure this component. The variance explained in these items was 41.62 percent. Component number two is 'work performance'. At first, this component measured using five items whereby from the item 8 to item 11 (see Table 2), meanwhile the loading factor of item number 12 was negative $(-0.378)$ or below than 0.50; therefore, it was dropped from the analysis. Consequently, only four items were used to measure this component. The variance explained by this scale is 25.39 percent.

\section{Descriptive Statistics, Reliability Test, Correlation Test, and Regression Analysis}

As it showed in Table 3, all the variables have mean values are more than 3.00. Meanwhile, the standard deviation for these variables is less than 1.00. For distributive justice, the mean is 3.67 and standard deviation is 0.79 . Whereas the mean for procedural justice is 3.41 and standard deviation is 0.79 . While, for interactional justice, the mean is 3.48 and standard deviation is 0.74 . For performance appraisal satisfaction, mean are 3.49 and standard deviation is 0.76 . Despite all variables, work performance has the highest mean 3.70 and the lowest standard deviation 0.46 . 
Table 3: Descriptive Statistics

\begin{tabular}{|l|c|c|}
\hline Variables & Mean & Standard Deviation \\
\hline Distributive Justice & 3.67 & 0.75 \\
\hline Procedural Justice & 3.41 & 0.79 \\
\hline Interactional Justice & 3.48 & 0.74 \\
\hline Performance Appraisal Satisfaction & 3.49 & 0.76 \\
\hline Work Performance & 3.70 & 0.46 \\
\hline
\end{tabular}

The reliability measures to which extent measure is without bias (error free) and offers consistent measurement across time and across the various in the instrument (Cavana, Delahaye, \& Sekaran, 2001). Interitem consistency is a test of consistency of respondent's answers to all the items in a measure. According to Cavana, Delahaye, and Sekaran (2001), the most popular test of inter-item consistency reliability is the Cronbach's coefficient alpha, which is used for multipoint scaled items. Table 4 shows the summary of variables included in this study, the number of items used for measuring each variables and reliability coefficient for each variable. In measuring organizational justice, there are three items were used, which are distributive justice, procedural justice and interactional justice. Number of item measured for each variable is five, seven and six items, while the Cronbach alpha is $0.90,0.94$ and 0.93 respectively. For performance appraisal satisfaction, number of item is seven and the Cronbach alpha is 0.93. Finally, there are four items being measured for work performance variable and its Cronbach alpha is 0.88 .

The Cronbach coefficient for the entire variables shows the value about than 0.80 . That means the value for each variable in this study is acceptable because according to Cavana, Delahaye and Sekaran (2001), the higher the coefficients, the better the measuring instrument.

Table 4: Descriptive Statistics

\begin{tabular}{|l|c|c|}
\hline Variables & $\begin{array}{l}\text { Number of } \\
\text { Items }\end{array}$ & $\begin{array}{l}\text { Cronbach } \\
\text { Alpha }\end{array}$ \\
\hline Organizational Justice & 5 & 0.90 \\
\hline - Distributive Justice & 7 & 0.94 \\
\hline - $\quad$ Procedural Justice & 6 & 0.93 \\
\hline - Interactional Justice & 7 & 0.93 \\
\hline $\begin{array}{l}\text { Performance Appraisal } \\
\text { Satisfaction }\end{array}$ & 4 & 0.88 \\
\hline Work Performance & 4 & \\
\hline
\end{tabular}

Correlation analysis is to show the strength of the association between the variables involved. Inter-correlations coefficients $(r)$ were calculated by using the Pearson's Product Moment. According to Cohen (1998), the correlation coefficient ( $r$ ) ranging from 0.10 to 0.29 may be regarded as indicating a low degree of correlation, $r$ ranging from 0.30 to 0.49 may be considered as a moderate degree of correlation, and $r$ ranging from 0.50 to 1.00 may be regarded as a high degree of correlation.
Table 5 shows the correlations between all the included variables in the study. The results indicate that performance appraisal satisfaction has the strongest correlation with interactional justice $(r=0.80, \mathrm{p}<0.01)$. Meanwhile, the least significant correlation was distributive justice $(r=0.61, p<0.01)$. The second highest correlation with procedural justice was distributive justice $(r=0.74, p<0.01)$. The procedural justice has the lowest correlation with work performance $(r=0.23, p<0.05)$. It is the lowest ranging among all the variables in this study. 
Table 5: Correlation of Variables

\begin{tabular}{l|l|c|c|c|c|}
\hline & DJ & PJ & IJ & PAS & WP \\
\hline Distributive Justice (DJ) & 1.00 & - & - & - & - \\
\hline Procedural Justice (PJ) & $0.742^{* *}$ & 1.00 & - & - & - \\
\hline Interactional Justice (IJ) & $0.569^{* *}$ & $0.663^{* *}$ & 1.00 & - & - \\
\hline $\begin{array}{l}\text { Performance Appraisal Justice } \\
\text { (PAS) }\end{array}$ & $0.615^{* *}$ & $0.680^{* *}$ & $0.813^{* *}$ & 1.00 & - \\
\hline Work Performance (WP) & $0.225^{* *}$ & $0.353^{* *}$ & $0.348^{* *}$ & $0.297^{* *}$ & 1.00 \\
\hline $\begin{array}{l}* * \\
*\end{array}<0.01$ level (2-tailed). \\
${ }^{*}<0.05$ level (2-tailed).
\end{tabular}

Besides than work performance, all the variables are significantly related with each other, and the correlation coefficients are more than $r=0.50 \quad(p<0.01)$. Meanwhile; work performance has the lowest significant correlation with all the variables. The correlation coefficient ranging for work performance with distributive justice $(r=0.23, p<0.05)$, procedural justice $(r=0.35, p<0.01)$, interactional justice $(r=0.35, p<0.01)$, and performance appraisal satisfaction $(r$ $=0.30, p<0.01)$. This concluded that, work performance has a very low effect on organizational justice and performance appraisal satisfaction in the performance appraisal system. By looking at the Table 5, it shows that all the variables are significantly correlated with all the related variables. Overall, the range of correlations coefficient is from $r=0.23$ to $r=0.81$. This shows that, all the variables have significant correlations between each other, and most of the variables are at the level of moderate to the high degree of correlation.

Multiple regression analysis was used to answer the research questions. In order to conduct the said regression analysis, several assumptions about the relationships between the dependent and the predictor variables must be met, mainly normality, linearity, constant variance of the error terms, and independent of the error terms. The main concern of this study is to find out whether the organizational justice has a significant impact on work performance and whether performance appraisal satisfaction mediates this relationship. The results revealed that:

a. The relationship between employee perceptions of organization justice in performance appraisal system and work performance is not significant. As shown in Table 6, the entire variables for organization justice are not influential. In order to be significant, the value must be between $p<0.001$ to $p<0.05$. The $\mathrm{R}$ square $\left(R^{2}\right)$ value was 0.15 , which mean there was 15 percent of variance in work performance and organizational justice (distributive, procedural and interactional justice). This result shows that, there is no significant relationship between employee perceptions of organizational justice of performance appraisal system and work performance. Therefore, Hypothesis 1 is not supported, or in the other words, the organizational justice has no positive impact on work performance.

Table 6: Regression Result of Organizational Justice and Work Performance

\begin{tabular}{|l|l|l|}
\hline Organizational Justice & Std $\boldsymbol{\beta}$ & Sig \\
\hline Distributive Justice & -0.12 & 0.40 \\
\hline Procedural Justice & 0.30 & 0.06 \\
\hline Interactional Justice & 0.22 & 0.86 \\
\hline $\mathrm{R}^{2}$ & 0.15 & \\
\hline Adjusted $\mathrm{R}^{2}$ & 0.13 & \\
\hline F-Value & 5.83 & \\
\hline Note: ${ }^{*} p<0.05,{ }^{* *} p<0.01,{ }^{* * *} p<0.001$ &
\end{tabular}


b. The relationship between employee perceptions of organization justice in performance appraisal system and performance appraisal satisfaction is mixed. Even though the R square $\left(\mathrm{R}^{2}\right)$ value was 0.70 , the independent variables, i.e. the distributive justice $(\beta=0.14)$ and procedural justice $(\beta=0.16)$ in organizational justice's coefficients were no statistically significant with performance appraisal satisfaction. Meanwhile, interactional justice $(\beta=0.63)$ has an influential impact on performance appraisal satisfaction $(p<0.001)$. Table 7 showed that, there were partial relationships between employee perception of organizational justice in performance appraisal system and performance appraisal satisfaction. In this study, the Hypothesis 2a (distributive justice) and Hypothesis 2b (procedural justice) was not supported, whereas simply Hypothesis 2c (interactional justice) was supported. It means that Hypothesis 2 organizational justice (distributive, procedural \& interactional) was only partially supported.

Table 7: Regression Result of Organizational Justice and Performance Appraisal Satisfaction

\begin{tabular}{|l|l|l|}
\hline Organizational Justice & Std $\boldsymbol{\beta}$ & Sig \\
\hline Distributive Justice & 0.14 & 0.11 \\
\hline Procedural Justice & 0.16 & 0.08 \\
\hline Interactional Justice & $0.63^{* * *}$ & 0.00 \\
\hline $\mathrm{R}^{2}$ & 0.70 & \\
\hline Adjusted $\mathrm{R}^{2}$ & 0.69 & \\
\hline F-Value & 76.12 & \\
\hline Note: ${ }^{*} p<0.05,{ }^{* *} p<0.01,{ }^{* * *} p<0.001$ &
\end{tabular}

c. The relationship between performance appraisal satisfaction and work performance is positive and statistically significant. Table 8 showed there was an influential relationship between performance appraisal satisfaction and work performance. The significant value was $0.003(\mathrm{p}<0.01$ and $\beta=0.30)$.

Table 8: Regression Result of Organizational Justice and Performance Appraisal Satisfaction

\begin{tabular}{l|l|l|}
\hline & Std $\boldsymbol{\beta}$ & Sig \\
\hline Performance Appraisal Satisfaction & $0.30^{* *}$ & 0.003 \\
\hline $\mathrm{R}^{2}$ & 0.09 & \\
\hline Adjusted $\mathrm{R}^{2}$ & 0.08 & \\
\hline F-Value & 9.47 & \\
Note: ${ }^{*} p<0.05,{ }^{* *} p<0.01,{ }^{* * *} p<0.001$ &
\end{tabular}

d. The test of relationship between employee perception of justice in performance appraisal system and work performance, which was mediated by performance appraisal satisfaction, could not be done due to the unfulfilled requirement. To test the mediation effect of performance appraisal satisfaction, Baron and Kenny (1986) proposed a fourstep approach. Step 1, it is imperative to show that there is a correlation ( $r$ ) between organization justice and work performance. Step 2, there should be a correlation between organization justice and performance appraisal satisfaction. Meanwhile in step 3, there should be a correlation between performance appraisal satisfaction and work performance. Finally step 4, when performance appraisal satisfaction and organizational justice (distributive, procedural and interactional justice) are entered together as the independent variable to work performance, mediation is supported if the partial direct effect of organizational justice to work performance is not significantly different 
from zero and the relationship between performance appraisal satisfaction and work performance is considerably greater than zero. However, the results of the mediated regression approach could not be mapped at the first step because there was no significant relationship between organizational justice (distributive, procedural and interactional justice) in performance appraisal system and work performance. This means that organizational justice does not have any effect on work performance. Therefore, the second and third step of Baron and Kenny (1986) cannot be continued.

\section{Implication to Managers}

Given the pivotal nature of performance appraisal in the strategic HRM (SHRM) process of any organization (see, for example, Delahaye, 2005 and Fisher, Schoenfeldt, \& Shaw, 1999), these cautionary messages do need to be highlighted. One of the important contemporary human-resource management issues is the retention of staff (Donaldson 2005) in which talent is the capable driver, whether for increasing or limiting the capability or capacity within the organization (Sullivan, 2005). Therefore, the firms need to manage the performance appraisal process for underperforming staff, both male and female. In particular, it is recommended that managers consider the importance of providing the unsuccessful appraisees with hope in the future. Specifically, managers should indicate that another, more developmental session, will follow in a few days to help those staffs to improve on the identified deficiencies and ensure that such a developmental intervention does indeed eventuate. Employees who receive good scores on their appraisals are generally motivated to perform well and maintain their productivity. Positive feedback on appraisals gives employees a feeling of worth and value, especially when accompanied by a raise.

In addition, managers need to recognize that performance appraisal systems are not one size fits all. Best practice may mean that performance systems need to be more open and flexible (Tattersall \& Morgan, 1997) in order to account for individual differences. Contemporary managers need to keep in mind that gender equity in the appraisal process does not mean treating all staff exactly the same and measuring the exact identical criteria.

Expectations about performance marks and the comparison of those marks with the previous year or with the other employee had a very strong influence over the level of satisfaction. The results from this study indicated that interactional justice is very important for the employee, compared with distributive and procedural justice. This can be achieved by improving interactional justice, giving the employee greater involvement throughout the performance appraisal process and also train all the participants who are involved so that they can use the feedback more effectively. This fact was supported by Moorman (1991), in which the perception of fairness based on interactional justice may be the easiest perception of fairness to manage. Distributive of outcome may be constrained by forces outside the manager's control. Similarly, the present or absence of equitable procedures may be a function of organization policy and not employees is often a matter of managers being sensitive to the interests of the employees and convincing them that it is the manager's interest to be fair.

\section{Conclusion and Future Recommendation}

Overall, the result from this study indicated that there was no significant relationship between the organizational justice and work performance. However, past researchers have led us to believe that there is an influential relationship between organizational justice in performance appraisal system, performance appraisal satisfaction and work performance. This research has shown the concern of employees towards performance appraisal satisfaction, especially on the performance appraisal feedback. Interactional justice is the most important factor for them during and after the performance appraisal process. A serious attention on this matter 
to obtain a better employees work performance should be given by management. This study also concluded that employee perception of organizational justice (distributive, procedural and interactional justice) in the performance appraisal system did not significantly contribute or have no impact to work performance.

\section{Future Research}

To get a factual and better image of the relationship between the fairness of organization justice and the performance appraisal system within the organization, a considerably larger sample size is required. Therefore, for the forthcoming studies, we propose that the future research should be a study in detail on perception of organizational justice in order to determine the satisfaction level and performance of the employees. A similar study may be conducted in the different sector, both private and public sectors and the said study may also include the testing of other variables, which might have a significant effect on work performance.

\section{References}

Ahmed, I., Ramzan, M., Mohammad, S. K. \& Islam, T. (2011). 'Relationship between Perceived Fairness in Performance Appraisal and OCB: Mediating Role of Organizational Commitment,' International Journal of Academic Research, 3 (5), 15-20.

Ahmed, S. (1999). "The Emerging Effectiveness for Human Resource Management: An Exploratory Study with Performance Appraisal," The Journal of Management Development, 18 (6), 543-556.

Alexander, S. \& Ruderman, M. (1987). "The Role of Procedural and Distributive Justice in Organizational Behavior," Social Justice Research, 1, 177-198.

Archer North \& Associatiates. (1998). 'Introduction to Performance Appraisal,' http://www.performance-

appraisal.com/intro.html [Accessed on Thursday, 12 January 2012).
Aquinis, H. (2007). 'Performance Management,' Upper Saddle River, NJ: Pearson Prentice Hall.

Baron, R. M. \& Kenny, D. A. (1986)."The Moderator-Mediator Variable Distinction in Social Psychological Research: Strategic and Statistical Considerations," Journal of Personality and Social Psychology, 51, 117382.

Bies, R. J. \& Moag, J. S. (1986). 'Interactional Justice: Communication Criteria of Fairness,' In Lewecki, R. J., Sheppard, B. H. \& Bazerman M. H. (Eds.) Research On Negotiation In Organizations, 1, 43-55. Greenwich, CT: JAI Press, Inc.

Byrne, Z. S. \& Cropanzano, R. (2001).'The History of Organizational Justice: The Founders Speak,' In Cropanzano (Ed.) Justice in the Workplace: From Theory to Practice, 3-26, Mahwah, NJ: Lawrence Erlbaum Associates, Inc.

Cavana, R. Y., Delahaye, B. L. \& Sekaran, U. (2001). 'Applied Business Quantitative and Qualitative Methods,' Sidney: John Wiley \& Sons.

Cohen-Charash, Y. \& Spector, P. E. (2001). "The Role of Justice in Organizations: A Meta-Analysis," Organizational Behavior and Human Decision Processes, 86 (2), 278321.

Colquitt, J. A., Conlon, D. E., Wesson, M. J., Porter, C. O. L. H. \& Yee Ng, K. (2001). "Justice at the Millennium: A Meta-Analytic Review of 25 Years of Organizational Justice Research," Journal of Applied Psychology, 86, 425-445.

Cook, J. \& Crossman, A. (2004). "Satisfaction with Performance Appraisal System: A Study of Role Perceptions," Journal of Managerial Psychology, Vol. 19, 526-541.

Delahaye, B. L. (2005). 'Human Resource Development: Adult Learning and Knowledge Management (2nd ed.),' Brisbane, Australia: John Wiley \& Sons. 
Fatt, C. K., Khin, E. W. S. \& Heng, T. N. (2010). "The Impact of Organizational Justice on Employee's Job Satisfaction: The Malaysian Companies Perspective," American Journal of Economics and Business Administration, 2 (1), 56-63.

Fernandes, C. \& Awamleh, R. (2006). "Impact of Organizational Justice in an Expatriate Work Environment," Management Resources News, 29 (11), 701712.

Fisher, C. D., Schoenfeldt, C. F. \& Shaw, J. B. (1997). 'Performance Appraisal,' Human Resource Management (3rd ed.) Boston: Houghton Mifflin.

Folger, R., Konovsky, M. A. \& Cropanzano, R. (1992). "A Due Process Metaphor for Performance Appraisal," In Staw, B. M. and Cummings, L.L. (Eds.), Research In Organizational Behavior, 14, 129-177. Greenwich, CT: JAI Press.

Foster, D. P., Stine, B. \& Waterman, R. (1998). Business Analysis Using Regression: A Casebook, US: SpringerVerlag.

Greenberg, J. (1986a). "Determinants of Perceived Fairness in Performance Evaluation," Journal of Applied Psychology, 71, 340-342.

Greenberg, J. (1986b). 'Determinants of Perceived Fairness of Performance Appraisal Evaluations,' in R. J. Lewieki, B. Shepard and M. Bazerman, (Eds.) Negotiations in Organizations. 25-41, Greenwich, CT: JAI Press.

Heslin, P. A. (1998). "Negotiating Effectively: The Role of Fairness," Journal of St. James Ethics Society. http://pheslin.cox.smu.edu/download/pub lications/Negotiating_effectively_role_of_fai rness.pdf[Accessed on Thursday, 12 January 2012].
Ismail, A., Zaidi Sulaiman, A., Al-Banna Mohamed, H. \& Mohd Sani, R. (2011). "Procedural Justice as a Moderator in the Relationship between Performance Appraisal Communication and Job Satisfaction," Negotium, 5, 162-186.

Jaccard, J., Turrisi, R. \& Wan, C. K. (1990). Interaction Effects in Multiple Regression, Newsbury Park, California: SAGE Publications, Inc.

Kavanagh, P., Benson, J. \& Brown, M. (2007). "Understanding Performance Appraisal Fairness," Asia Pacific Journal of Human Resources, 45 (2), 132-150.

Kuvaas, B. (2006). "Performance Appraisal Satisfaction and Employee Outcomes: Mediating and Moderating Roles of Work Motivation," International Journal of Human Resource Management, 17 (3), 504522.

Landy, F. J., Barnes, J. L. \& Murphy, K.R. (1978). "Correlates of Perceived Fairness and Accuracy of Performance Evaluation," Journal of Applied Psychology, 63, 751-754.

Landy, F. J. \& Farr, J. L. (1980). "Performance Rating," Psychological Bulletin, 87, 1, 72-107.

Longenecker, C. O., \& Goff, S. J. (1992). "Performance Appraisal Effectiveness: A Matter of Perspective," Advanced Management Journal, 57, 2, 18-23.

Mohrman, A. M., Resnick-West, S. M. \& Lawler III, E. E. (1989). Designing Performance Appraisal Systems: Aligning Appraisals and Organizational Realities, San Francisco: Jossey-Bass.

Moorhead, G. \& Griffin, R.W. (1992). 'Organizational Behavior,' 3rd ed. Boston: Houghton Mifflin Company. 
Moorman, R. H. (1991). "Relationships between Organizational Justice and Organizational Citizenship Behaviors: Do Fairness Perceptions Influence Employee Citizenship?," Journal of Applied Psychology, $76,845-855$.

Pettijohn, C. E., Pettijohn, L. S. \& Taylor, A. J. (2000). "An Exploratory Analysis of Salesperson Perceptions of the Criteria Used in Performance Appraisals, Job Satisfaction and Organizational Commitment," The Journal of Personal Selling and Sales Management, Vol. 20 No 2, 77-80.

Pettijohn, C., Pettijohn, L. S., Taylor, A. J. \& Keillor, B. D. (2001). "Are Performance Appraisals a Bureaucratic Exercise or Can They be Used to Enhance Sales-Force Satisfaction and Commitment?," Psychology \& Marketing, Vol. 18 No. 4, 337-364.

Richard, L. (2010). "The Effects of Performance Appraisal on Organizational Performance,"

http://smallbusiness.chron.com/effectsperformance-appraisal-organizationalperformance-1762.html [Accessed on Thursday, 12 January 2012].

Robbins, S. \& Judge, T. (2007). 'Organizational Behavior' 12th ed," Upper Saddle River, NJ: Prentice Hall.

Sabeen, Z. \& Mehbob, A. A. A. (2008). 'Perceived Fairness of and Satisfaction with Employee Performance Appraisal and Its Impact on Overall Job Satisfaction,' The Business Review - Cambridge, 10 (2), 185192.

Sekaran, U. (2003). Research Methods for Business (4th ed.), Hoboken, NJ: John Wiley \& Sons.

Seldon, S. C., Ingraham, P.W. \& Jacobson, W. (2001). "Human Resource Practices in State Government: Findings from a National Survey," Public Administration Review, 61, 598-614.

Shen, J. (2004). “International Performance Appraisal: Policies, Practices and Determinant in the Case of Chinese
Multinational Companies," International Journal of Manpower, 25 (6), 547-563.

Skarlicki, D. P. \& Folger, R. (1997). "Retaliation in the Workplace: The Roles of Distributive, Procedural, and Interactional Justice," Journal of Applied Psychology, 82, 434-443.

Suliman, A. M. T. (2007). "Links between Justice, Satisfaction, and Performance in the Workplace: A Survey in the UAE and Arabic Context," Journal of Management Development, 26 (4), 294-311.

Sullivan, J. (2005). "Talent Management: To Build, Buy or Trade?," Human Resources, 77, 14-15.

Tabachnick, B. G. \& Fidell, L. S. (2001). Using Multivariate Statistics, Sydney: Allyn \& Bacon.

Tattersall, A. J. \& Morgan, C. A. (1997). "The Function and Effectiveness of Dynamic Task Allocation," in D. Harris, (Ed). Engineering Psychology and Cognitive Ergonomics: Integration of Theory and Application, Aldershot: Avebury.

Thomas, S. L. \& Bretz, R. D. (1994). "Research and Practice in Performance Appraisal: Evaluating Performance in America's Largest Companies," SAM Advanced Management Journal, 22 (2), 2837.

Vance, C. M., McClaine, S. R., Boje, D. M. \& Stage, H. D. (1992). "An Examination of the Transferability of Traditional Performance Appraisal Principles across Cultural Boundaries," Management International Review, 32 (4), 313-326.

Wong, C., Hui, C. \& Law, K. S. (1995). 'Causal Relationships between Attitudinal Antecedents to Turnover,' Academy of Management Journal, 41, 342-346.

Yaacob, M. R. (2008). 'SPSS for Business and Social Science Students,' Malaysia: Pustaka Aman Press. 